\title{
Professor Hu Zhihong: The New President of the Society for Invertebrate Pathology
}

\author{
Basil Arif $^{1}$ (D) Jiali Si ${ }^{2} \cdot$ Zheng-Li Shi $^{2}$
}

Received: 27 September 2018 / Accepted: 30 September 2018/Published online: 23 October 2018

(c) Wuhan Institute of Virology, CAS and Springer Nature Singapore Pte Ltd. 2018

The Society for Invertebrate Pathology (SIP) is foremost in the world covering all aspects of related research in insect virology, bacteriology, mycology, parasitology and microbial control. The SIP has a wide scientific appeal with members from many countries spanning every continent in the globe. Election of members to the Society's Governing Council is based on scientific standing, contributions, reputation and involvement in the activities of the Society. At the recent annual meeting in August 2018, in the Gold Coast of Australia, Prof. Hu Zhihong was inaugurated as the President of the SIP having been elected by worldwide members to take charge of the Society's activities, direction and scientific standing. Prof. Hu's qualifications as a scientist and a leader are impeccable and far-reaching. Her outstanding scientific achievements, salient contributions to the field of virology and innovative approaches to research made her a world-renowned scientist. She has so far published no less than 150 manuscripts, mostly in internationally refereed scientific journals. Her contributed and invited presentations at the annual meetings of the Society often reflected the state-of-the-art in molecular virology. All this gave members of the SIP ample reasons to elect her as the President. Her experience as a past Director General of the Wuhan Institute of Virology of the Chinese Academy of Sciences will help her immensely in

Basil Arif

basil.arif@canada.ca

1 Scientist Emeritus, Laboratory for Molecular Virology, GLFC, Sault Ste. Marie P6A 2E5, Canada

2 Wuhan Institute of Virology, Chinese Academy of Sciences, Wuhan 430071, China running and directing the SIP to achieve even greater heights. No doubt, she will be an exceptional President.

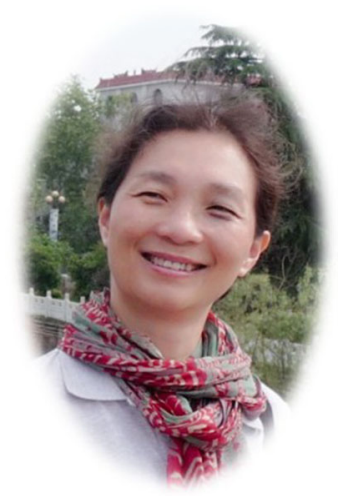

Prof. Hu Zhihong's journey in science started in the 1990s when she was awarded the prestigious Marie Curie global fellowship to embark on a joint PhD program at the Department of Virology of the University of Wageningen, The Netherlands and at the Wuhan Institute of Virology of the Chinese Academy of Sciences. She earned her PhD in 1998 and has since been advancing both the basic and applied aspects of insect viruses. Her notable achievements in genomics, proteomics and transcriptomics of baculoviruses, molecular mechanisms of baculovirus infection, and virus-related bio-techniques in microbial control have received wide acclaim and published in high impact international journals (Chen et al. 2001; Sun et al. 2005; Wang et al. 2010; Xing et al. 2017). One her more recent and remarkable accomplishments is the in vitro synthesis of the Autographa californica nucleopolyhedrovirus (AcMNPV) from a bioinformatics file (Shang et al. 2017). By using a combination of PCR and transformation-associated recombination in yeast, the viral genome was synthesized in vitro (AcMNPV-WIV-Syn1) and was infectious to tissue culture cells. Progeny virus was structurally and functionally indistinguishable from the parental AcMNPV. This new platform opened the door to wide genome editing 
such as deleting and/or adding a number of genes, producing an effective expression vector with a minimal genome and even a better biocontrol agent. This is the largest DNA synthesized so far and should be an impetus to stimulate similar advancements with other large DNA viruses. This accomplishment coincided with her research on the per os infectivity factors (pifs) with the synthetic genome providing an avenue to delete pifs totally and produce a virus ineffective against the natural host but replicates in tissue culture cells. Prof. Hu's studies also revealed the association of pifs with viral host range and specificity.

Besides research on insect viruses, Prof. Hu also studies tick borne viruses (especially bunyaviruses), identification and isolation of new viruses, phylogeny, pathogenesis, etc (Guo et al. 2012; Ning et al. 2015; Shi et al. 2018). She also delves into other viruses such as SARS-coronavirus, cynophage, and others (Li et al. 2005; Xia et al. 2013).

The research on insect virology in China has been advancing rapidly due to the commitment of dedicated mission-oriented scientists and excellent support. Indeed, China is fast becoming the world's leader in research on insect virology. Young scientist such as Prof. Hu played important roles to advance our knowledge in all aspects of the field. Equally critical is her continued obligation to educate and mentor younger generation of virologists such as graduate students and post-doctoral fellows by imparting her vast knowledge as well as instilling into them the passion for science and research.

Prof. Hu co-authored the classic college textbook "General Virology" (in Chinese) that has served as a reference for students majoring in virology for more than a decade (Xie and $\mathrm{Hu}$ 2002). She also serves as an editor of many scientific journals, such as Virologica Sinica, Chinese Science Bulletin and the Journal of Invertebrate Pathology.

This is the first time in the 50 years' history that the SIP has elected a scientist outside Europe or North America to be its President. This election is not only an affirmation of the outstanding scientific achievements and leadership of
Prof. Hu, but also a testament to the expanding influence of Chinese scientists in the international scientific arenas.

We congratulate Prof. Hu Zhihong for a well-deserved honour.

\section{References}

Chen X, IJkel WF, Tarchini R, Sun X, Sandbrink H, Wang H, Peters S, Zuidema D, Lankhorst RK, Vlak JM, Hu Z (2001) The sequence of the Helicoverpa armigera single nucleocapsid nucleopolyhedrovirus genome. J Gen Virol 82:241-257

Guo Y, Wang W, Ji W, Deng M, Sun Y, Zhou H, Yang C, Deng F, Wang H, Hu Z, Lou Z, Rao Z (2012) Crimean-Congo hemorrhagic fever virus nucleoprotein reveals endonuclease activity in bunyaviruses. Proc Natl Acad Sci USA 109:5046-5051

Li W, Shi Z, Yu M, Ren W, Smith C, Epstein JH, Wang H, Crameri G, Hu Z, Zhang H, Zhang J, McEachern J, Field H, Daszak P, Eaton BT, Zhang S, Wang LF (2005) Bats are natural reservoirs of SARS-like Coronaviruses. Science 310:676-679

Ning YJ, Feng K, Min YQ, Cao WC, Wang M, Deng F, Hu Z, Wang $H$ (2015) Disruption of type I interferon signaling by the nonstructural protein of severe fever with thrombocytopenia syndrome virus via the hijacking of STAT2 and STAT1 into inclusion bodies. J Virol 89:4227-4236

Shang Y, Wang M, Xiao G, Wang X, Hou D, Pan K, Liu S, Li J, Wang J, Arif BM, Vlak JM, Chen X, Wang H, Deng F, Hu Z (2017) Construction and rescue of a functional synthetic baculovirus. ACS Synth Biol 6:1393-1402

Shi J, Hu Z, Deng F, Shen S (2018) Tick-borne viruses. Virol Sin 33:21-43

Sun X, Sun X, Bai B, Van Der Werf W, Vlak JM, Hu Z (2005) Production of polyhedral inclusion bodies from Helicoverpa armigera larvae infected with wild-type and recombinant HaSNPV. Biocontrol Sci Technol 15:353-366

Wang R, Deng F, Hou D, Zhao Y, Guo L, Wang H, Hu Z (2010) Proteomics of the Autographa californica nucleopolyhedrovirus budded virions. J Virol 84:7233-7242

Xia H, Li T, Deng F, Hu Z (2013) Freshwater cyanophages. Virol Sin 28:253-259

Xie T, Hu Z (2002) General virology (ISBN: 9787030107275). Science Press, Beijing (in Chinese)

Xing L, Yuan C, Wang M, Lin Z, Shen B, Hu Z, Zou Z (2017) Dynamics of the interaction between cotton bollworm Helicoverpa armigera and nucleopolyhedrovirus as revealed by integrated transcriptomic and proteomic analyses. Mol Cell Proteomics 16:1009-1028 